Boletín de la Sociedad Geológica Mexicana

VOLUMEN 61, NÚM. 2, 2009, P. 233-238

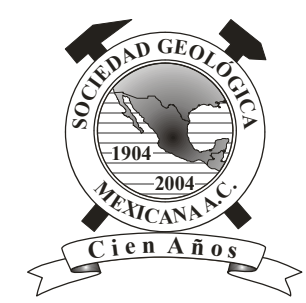

\title{
Occurrence of a second ichthyosaur genus (Reptilia: Ichthyosauria) in the Late Jurassic Gulf of Mexico
}

\author{
Marie-Céline Buchy ${ }^{1, *}$, José Guadalupe López Oliva \\ ${ }^{1}$ Museo del Desierto, Saltillo, Coahuila, Mexico \\ ${ }^{2}$ Universitad Autónoma de Nuevo León, Facultad de Ciencias de la Tierra, Linares, Nuevo León, Mexico \\ *mobuchy@gmail.com
}

\begin{abstract}
The forefin of the recently excavated partial skeleton of a large ichthyosaur is here described. The specimen comes from the upper Tithonian (Upper Jurassic) La Caja Formation in the south of Coahuila State. The anatomy of the forefin as well as of those currently visible parts of the skull demonstrates it likely represents an Ophthalmosauridae, in any case it is distinct from Ophthalmosaurus, possibly close to Brachypterygius. Although generally poorly diagnostic, Late Jurassic Mexican ichthyosaurian remains are relatively abundant; a single specimen was surely identified as belonging to Ophthalmosaurus. The new specimen is therefore the first evidence of the presence of a second ichthyosaurian genus in the Late Jurassic Mexican Gulf.
\end{abstract}

Keywords: ichthyosauria, ophthalmosauridae, Mexico, Upper Jurassic, La Caja Formation.

\section{Resumen}

Se describe aqui la aleta delantera de un esqueleto parcial de un ictiosaurio de gran tamaño, encontrado recientemente. El especimen proviene del Titoniano superior (Jurásico Superior) de la Formación La Caja en el sur de Coahuila. La anatomia de la aleta y de las partes visibles del craneo, demuestran que probablamente representa un Ophthalmosauridae; aunque es sin duda distinto de Ophthalmosaurus, y probablamente cercano a Brachypterygius. A pesar de ser por lo general poco diagnósticos, los restos de ictiosaurios del Jurásico Tardio en México son relativemente abundantes; de estos, solamente un especimen ha sido identificado como perteneciente a Ophthalmosaurus. El nuevo ejemplar representa entonces la primera evidencia de la presencia de un segundo género de ictiosaurio en el Golfo méxicano del Jurásico Tardio.

Palabras clave: ichthyosauria, ophthalmosauridae, México, Jurásico Tardio, Formación La Caja. 


\section{Introduction}

A decade of exploration and work in Mexican collections demonstrated that the Late Jurassic Mexican Gulf was populated by a varied, if still enigmatic, assemblage of marine reptiles (Buchy et al., 2006c; Buchy, 2007, 2008, in press; material under study). All known Late Jurassic Mexican marine reptiles proceed from the coeval La Caja / La Casita / La Pimienta Fms (e.g. Adatte et al., 1994, 1996; Goldhammer, 1999; Goldhammer and Johnston, 2001). The assemblage comprises thalattosuchians, including two local species (Frey et al., 2002; Buchy et al., 2006d), pliosaurs and rare elasmosaur and cryptoclidid remains (Buchy et al., 2003, 2006a; Buchy, 2008, material under study). Ichthyosaurs are numerous but generally poorly diagnostic due to their fragmentary condition (Buchy, 2007, in press). It should be noted that for material collected prior to our work, especially when collected by non-professionals, it cannot be ascertained that the specimens were not more complete prior to collection; however, recent institutional field work in specific localities (e.g. in Gomez Farías, Coahuila; Buchy et al., 2006b) indeed yielded numerous isolated ichthyosaurian remains (mostly vertebrae). The genus Ophthalmosaurus was recently documented for the first time in Mexico, leading to the suggestion that most ichthyosaurian remains from the Late Jurassic Mexican Gulf actually represent members of that genus, and a low diversity in an area possibly favored for parturition (Buchy, in press). Recently, a COECYT grant allowed excavation and ongoing preparation of a large specimen from the south of Coahuila (Figure 1). Preparation of the partial forefin is now completed, and its description herein given: the specimen provides anatomical evidence of the presence of a second genus of ichthyosaur in the Late Jurassic Mexican Gulf.

\section{Institutional abbreviations}

COECYT: Consejo Estatal de Ciencia y Tecnología, Coahuila, Mexico; MUDE: Museo del Desierto, Saltillo, Coahuila, Mexico; UANL-FCT: Universitad Autónoma de Nuevo León, Facultad de Ciencias de la Tierra, Linares, Nuevo León, Mexico.

\section{Systematic palaeontology}

Order Ichthyosauria de Blainville, 1835

Family Ophthalmosauridae Baur, 1887

Ophthalmosauridae indet.

CPC 307, MUDE

Figures 2, 3

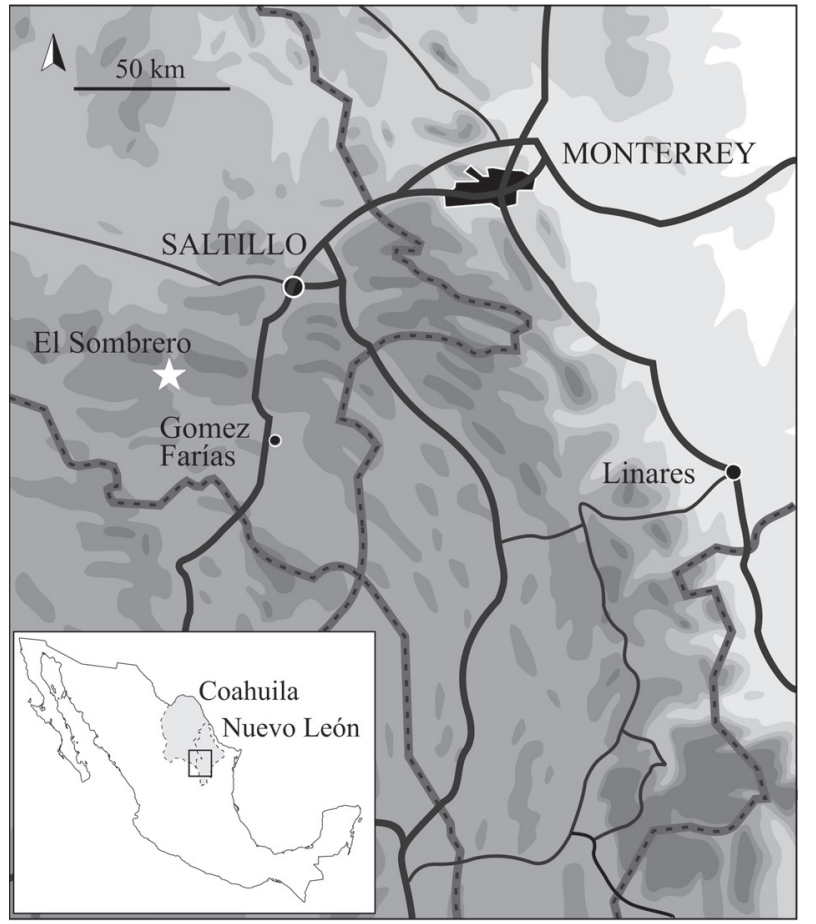

Figure 1: Map of Mexico (insert) and detail of south-east Coahuila and central Nuevo León; the area of the find is shown by a star.

\subsection{Material and origin}

The specimen consists of a long calcareous nodule fragmented by local tectonics, enclosing the skull, dorsal vertebral column and partial ribs; an additional, smaller nodule here considered comprises the partial pectoral girdle (both coracoids, right scapula and possibly one clavicle preserved as a partial imprint) and partial right forelimb (orientation of the humerus follows McGowan and Motani, 2003). All elements are preserved in 3-dimensions. The total length of the specimen is $5 \mathrm{~m}$, and current preparation status suggests the last preserved vertebrae represent the first caudals. Skull length is $1.6 \mathrm{~m}$. The first fragments were collected by Don Rodolfo Medellin González, son-in-law of the owner of the El Sombrero Ranch, Don Juan Pablo de la Cruz Sánchez. Following the wise advise of his wife, Don Rodolfo donated the pieces to MUDE. Institutional field campaigns conducted in 2008 by teams of MUDE with financial support from COECYT discovered more fragments including the complete cranium and mandible. Mechanical preparation is ongoing, performed at MUDE with financial support from COECYT by the senior author, I.A. Oyervides Salazar, Z.M. Casas García and J.A. Robledo García.

\subsection{Locality and horizon}

The specimen comes from the La Caja Fm at the El Sombrero Ranch, Sierra de Parras, Municipio de Saltillo, Coahuila, Mexico (2508'19' N, 101 ${ }^{\circ} 28^{\prime} 58^{\prime}$ ' W; Figure 1). 


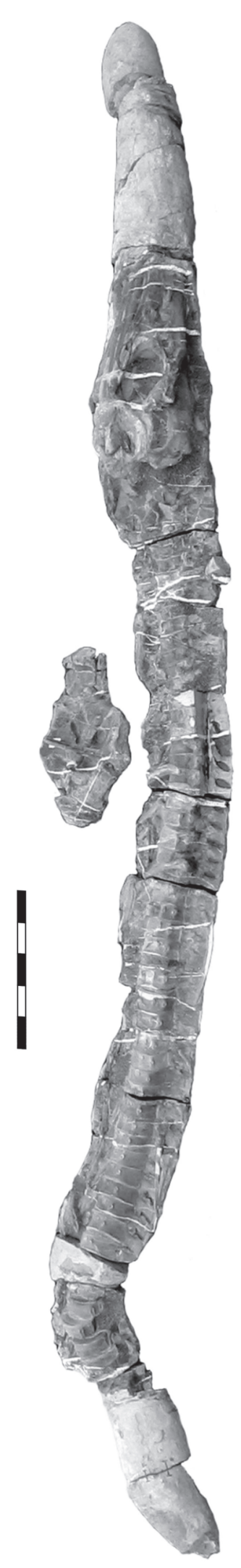

Figure 2: CPC 307 (MUDE), Ophthalmosauridae indet., left lateral view of the specimen in its current preparation status. Scale bar $500 \mathrm{~mm}$. Under this view, the right humerus is seen in dorsal aspect (see Figure 3A).
Preliminary microfossil analyses conducted at UANL-FCT indicate a late Tithonian age for the specimen, owing to the presence of the calpionellid Crassicolaria massutiniana.

\subsection{Preservation}

Better preservation of the bone on the left side of the specimen likely indicates the carcass rested on this side. The elements of the girdle are disarticulated, some are missing (e.g. the left scapula) as are the left forefin and both hindfins; it is impossible to assess, whether they were present prior to weathering by the adjacent Pleistocene river, were lost during early excavation, or were missing already prior to fossilization. The right forelimb is preserved ventral to the vertebral column (Figure 2); the right humerus is visible in dorsal view when the skull and vertebral column are viewed in left lateral view. The fin points toward the vertebral column. The postaxial part of the fin, however, kept its caudal orientation in respect to the skull and body. The forelimb is in articulation, except that the radius, ulna, intermedium and several proximal phalanges (and/ or metacarpals) are preserved tilted $90^{\circ}$ with respect to the humerus and rest of the forefin. Consequently, they are visible in proximal articular view between the humerus and distal phalanges all visible in dorsal view (when the skull and vertebral column are visible in left lateral view). The proximal-most postaxial accessory element presumably rotated a further $90^{\circ}$ toward distally and appears now visible in ventral view over phalanges visible in dorsal view. The presence of rib fragments resting on both sides of the humerus indicates disturbance of the carcass in an advanced stage of decay.

The articular head of the humerus is missing. Indeed, the proximal portion of the humerus, viewed end-on, presents two different types of preservation. Weathering of the edge of the nodule can be suggested to be responsible for the lack of the ventral part of the proximal portion of the humerus. In contrast, the dorsal part of the proximal portion of the humerus was covered with sediment and appears deeply concave, so much that preparation did not expose the bone yet; indeed, only a mm-thin layer of bone forms the dorsal margin of the humerus. Furthermore, portions of two ribs (presumably pertaining to the two ribs resting on the dorsal face of the humeral shaft) are present within the concave portion of the humeral extremity: they are represented by broken fragments dorsally, and parallel, curved sections more ventrally. These rib fragments indicate that the dorsal part of the proximal portion of the humerus was missing already at an early stage of decay, possibly poorly ossified, this possibly due to pathology. Further preparation is necessary to clarify this point.

Hence, the fin appears to have been disarticulated, possibly aided by a pathological humeral articulation, and to have undergone shifting presumably before the body finally rested on the sea floor; however, elucidation of the detailed taphonomic history of the specimen is pending completion 
of preparation and geological studies at the locality.

\section{Description of the forefin (Figure 3)}

\subsection{Humerus}

Thanks to the absence of its proximal portion, a crosssection of the humerus is visible, perpendicular to the shaft and situated likely close to the proximal extremity of the shaft (see the proportions of the various humeri illustrated by McGowan and Motani [2003: 33-35]: the humerus is the narrowest at mid-shaft, and its width there approximately equals half the proximodistal length of the bone). The crosssection emphasizes the dorsally triangular profile given by the median, prominent dorsal process (see McGowan and Motani, 2003), while the ventral profile is more rounded and asymetrical, the deltopectoral crest being less expressed and cranially situated.

Distally, the cranial (preaxial) margin of the humerus is rounded, in contrast to the cranially pointed 'leading edge' described in Ophthalmosaurus by McGowan and Motani (2003).

The distal articular portion of the humerus is partly obscured by two overlying ribs. However, from what is visible, the presence of three facets can be deduced, the cranial one (for the radius) being the longest, the central one (for the intermedium) the shortest.

\subsection{Radius}

The overall shape in planar aspect of the radius is poorly visible, due to compaction against elements of the metacarpus. Its proximal articular surface is gently concave, and markedly pitted.

\subsection{Ulna}

The ulna is suboval in planar view, with a distopostaxial facet for articulation with the proximal-most postaxial accessory element. Its proximal articular surface is possibly subcircular (but obscured by two overlying ribs) viewed end-on; the surface is poorly ornamented, in contrast to the condition of the radius, and without marked convexity.

\subsection{Other elements of the forefin}

The intermedium is trapezoidal in planar view, its shortest face the proximal one. Its proximal articular surface may be gently convex, with no marked pitting; however, preservation may be poor. Other metacarpals are not identifiable, being presumably preserved compressed against the first row of elements.

The proximal-most postaxial accessory element articulating with the ulna is trapezoidal, its postaxial margin gently convex, its preaxial margin straighter and shorter.
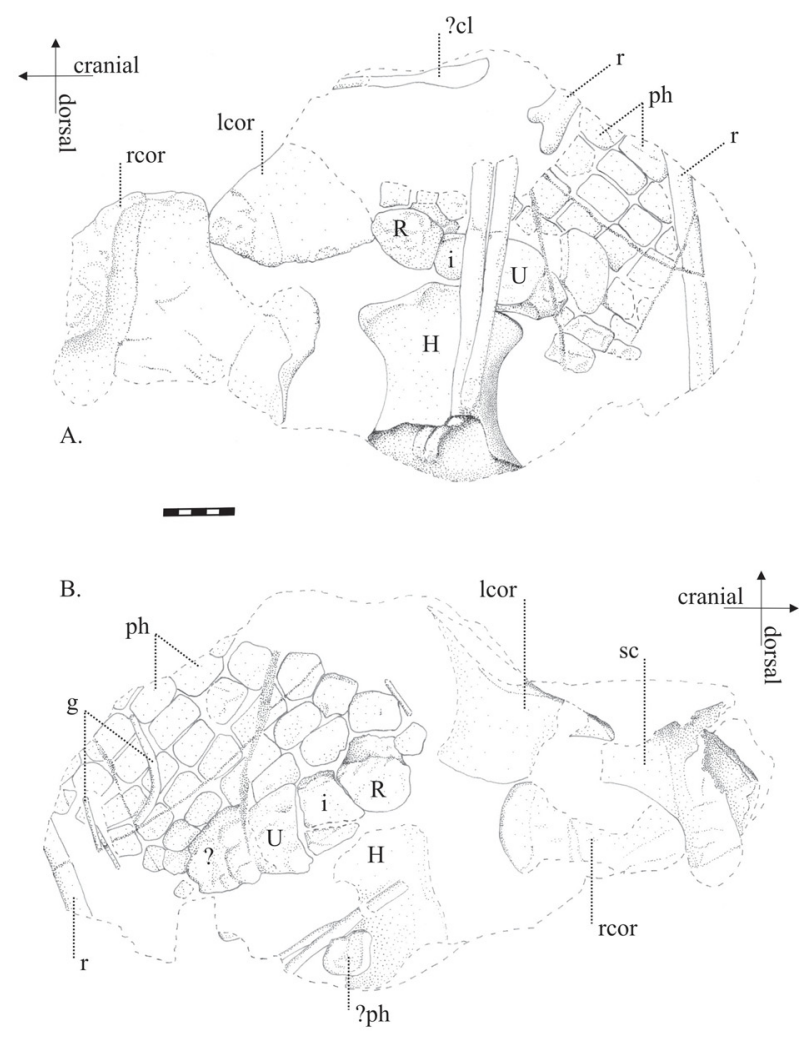

Figure 3: CPC 307 (MUDE), Ophthalmosauridae indet., interpretative drawings of the nodule containing the partial girdle and right forelimb, in $\mathrm{A} /$ left lateral view; $\mathrm{B} /$ right lateral view (in respect to the orientation of the skull and vertebral column). In $\mathrm{A} /$ the right humerus is visible in dorsal aspect; in $\mathrm{B} /$ it is visible in ventral aspect. Scale bar $50 \mathrm{~mm}$. Abbreviations: ?cl: possible clavicle fragment preserved as partial imprint; g: gastralia; $\mathrm{H}$ : right humerus; i: intermedium; lcor: left coracoid; ph: phalanges; R: radius; r: ribs; rcor: right coracoid; sc: scapula; $\mathrm{U}$ : ulna.

It corresponds in shape and size relative to other elements of the fin to what was described by McGowan (1997) for Brachypterygius.

Six digits are present. The proximal phalanges of the preaxial and postaxial digits are hexagonal to rounded, while the phalanges of the other digits are subrectangular, and closely fitting together. Where visible in marginal view, they present shallow articular facets for other phalanges

\section{Discussion}

\subsection{Comparative Paleontology.}

Among diagnostic features of Ophthalmosauridae listed by McGowan and Motani (2003), the cranial features (extracondylar area of the basioccipital and extent of the angular) are not yet visible in CPC 307; the specimen does possess an extra preaxial digit. Owing to close similarities to Brachypterygius (see further), it likely represents a member of Ophthalmosauridae; it is to be noted that all Late Jurassic and Cretaceous ichthyosaurs are considered by McGowan 
and Motani (2003) to represent ophthalmosaurids.

CPC 307 differs from Ophthalmosaurus in the respective size of the humerus distal facets and in the shape of the phalanges; the orbit also appears smaller compared to mandible length (orbital ratio is approximately 0.12 ) than it is in Ophthalmosaurus (orbital ratio $>0.2$ according to McGowan and Motani, 2003). CPC 307 is also much larger than reported specimens referred to Ophthalmosaurus (e.g. Kirton, 1983; Motani, 2005).

CPC 307 also clearly differs from Nannopterygius (Kimmeridgian of England) whose humerus is reduced in size and bears only two distal facets (McGowan and Motani, 2003).

In Caypullisaurus (Tithonian of Argentina), the median facet on the humerus is large and houses a polygonal element, likely the radius (Fernández, 1997, 1998), in contrast to the condition in CPC 307. Limb construction (humerus/zeugopodium contact) in Platypterygius also markedly differs from what is seen in CPC 307 (Bardet and Fernández, 2000; McGowan and Motani, 2003). CPC 307 cannot at present be compared to the holotypes of Mollesaurus (Bajocian of Argentina; Fernández, 1999) and Unodosaurus (Tithonian of Russia; Efimov, 1999; Maisch and Matzke [2000] consider the genus a synonym of Ophthalmosaurus but it is retained by McGowan and Motani [2003]), and hardly to material referred to Aegirosaurus (Tithonian of Germany; Bardet and Fernandéz, 2000). The latter genus is composed of a lost holotype and two referred specimens, including a juvenile; although forelimb structure is similar to that of Brachypterygius and CPC 307, the orbit in Aegirosaurus is larger (orbital ratio 0.18 to 0.2 ) than CPC 307 's, and known specimens are much smaller (less than 2 $m$ in length) than CPC 307. However, both overall size and size of the orbit can be related to ontogeny, and conclusions are pending completion of the preparation of CPC 307.

CPC 307 shares with Brachypterygius (KimmeridgianTithonian of England, Russia and Madagascar, McGowan and Motani, 2003) a large overall size, a relatively small orbit, and the morphology of the humerus and rest of the forefin, especially the trapezoidal intermedium articulating with the short, median facet on the humerus (McGowan, 1997). However, further preparation of the skull of CPC 307 is necessary to confirm affinities.

\subsection{Late Jurassic Mexican ichthyosaurs}

Apart from poorly diagnostic vertebral material (but abundant compared to remains of other taxa), a single, subcomplete specimen was assigned to Ophthalmosaurus (Buchy, in press). CPC 307 in turn is clearly distinct from Ophthalmosaurus, and therefore represents the evidence of the presence in the Late Jurassic Mexican Gulf of a second ichthyosaur genus, possibly related to Brachypterygius. As mentioned elsewhere, however, the currently known ichthyosaur diversity in the Late Jurassic Mexican Gulf appears low compared to coeval realms (Buchy, in press).
It is expected that further work in collections (including private ones) and in the field will bring new material and help assess the actual ichthyosaur diversity and the hypothesis that the Gulf possibly constituted a protected area favored for parturition (Buchy, in press).

\section{Acknowledgments}

Thanks are due to R. Medellin Gonzaléz and J.P. de la Cruz Sánchez for their admirable stubbornness in collecting fragments of the ichthyosaur and their open-mindedness, as well as to C.R. Delgado de Jesús (Secretaria de Educación Pública, Coahuila). Preparation is excellently performed by I.A. Oyervides Salazar, Z.M. Casas García and J.A. Robledo García (all MUDE). V. Cardena Beraza (UANL-FCT) made the thin-sections in record time. Field work was possible thanks to L.G. De León Saucedo, L.A. Esparza Pelletier, J. Flores Medina, B. García Almansa, R.A.K. Rosas Reyna and J.A. Sánchez Sífuentes. This work benefited from the support of the MUDE team, past and present, especially M. Martínez Valdés. Thanks are due also to F. Vega Vera and the organizing team of the XI Congreso Nacional de Paleontología (Querétaro, 2009). Fieldwork permit was obtained via INAH Coahuila. Essential financial support comes from COECYT (grant COAH-2008-C04-37); having obtained this grant owes much to G.A. Torres Valdés (COECYT) and B. Valdez Silva (MUDE). The manuscript greatly benefited from the comments of Editor F. Vega Vera (UNAM) and of both reviewers M. Fernández (La Plata) and J.A. Massare (Brockport).

\section{References}

Adatte, T., Stinnesbeck, W., Remane, J., 1994, The Jurassic-Cretaceous boundary in Northeastern Mexico. Confrontation and correlations by microfacies, clay mineral mineralogy, calpionellids and ammonites: Geobios, 17, 37-56.

Adatte, T., Stinnesbeck, W., Remane, J., Hubberten, H., 1996, Paleooceanographic change at the Jurassic-Cretaceous boundary in the western Tethys, northeastern Mexico: Cretaceous Research, 17, 671-689.

Bardet, N., Fernández., M.S., 2000, A new ichthyosaur from the Upper Jurassic lithographic limestones of Bavaria: Journal of Paleontology, 74, 503-511.

Baur, G., 1887, Über den Ursprung der Extremitäten der Ichthyopterygia: Jahresberichte und Mitteilungen des Oberrheinischen geologischen Vereines, 20, 17-20.

Blainville, H.D. de, 1835, Description de quelques espèces de reptiles de la Californie, précédée de l'analyse d'un système général d'Erpetologie et d'Amphibiologie: Nouvelles Annales du Muséum National d'Histoire naturelle, Paris, 4, 233-296.

Buchy, M.-C., 2007, Mesozoic marine reptiles from north-east Mexico: description, systematics, assemblages and palaeobiogeography: University of Karlsruhe, Germany, unpublished $\mathrm{PhD}$ thesis. Available online at: http://digbib.ubka.uni-karlsruhe.de/volltexte/1000007307.

Buchy, M.-C., 2008, Reevaluation of the holotype of Plesiosaurus (Polyptychodon) mexicanus Wieland, 1910 from the ?Upper Jurassic of Mexico: a thalattosuchian, not a sauropterygian: Revista Mexicana de Ciencias Geologicas, 25, 517-522. 
Buchy, M.-C., in press, First record of Ophthalmosaurus (Reptilia: Ichthyosauria) from the Tithonian (Upper Jurassic) of Mexico: Journal of Paleontology.

Buchy, M.-C., Frey, E., Stinnesbeck, W., López Oliva, J.G., 2003, First occurrence of a gigantic pliosaurid plesiosaur in the Late Jurassic (Kimmeridgian) of Mexico: Bulletin de la Société géologique de France, 174, 271-278.

Buchy, M.-C., Frey, E., Salisbury, S.W., Stinnesbeck, W., López Oliva, J.G., Götte M., 2006a, An unusual pliosaur (Reptilia, Sauropterygia) from the Kimmeridgian (Upper Jurassic) of northeastern Mexico: Neues Jahrbuch für Geologie und Paläontologie, 240, 241-270.

Buchy, M.-C., Frey E., Stinnesbeck, W., González González, A.H., 2006b, A new Tithonian (Upper Jurassic) marine vertebrate concentration Lagerstätte in north-eastern Mexico. Hantkeniana, 5, 17-19.

Buchy, M.-C., Frey, E., Stinnesbeck, W., López Oliva, J.G., 2006c, An annotated catalogue of the Upper Jurassic (Kimmeridgian and Tithonian) marine reptiles in the collections of the Universidad Autónoma de Nuevo León, Facultad de Ciencias de la Tierra, Linares, Mexico: Oryctos, 6, 1-18.

Buchy, M.-C., Vignaud, P., Frey, E., Stinnesbeck, W., González González A.H., 2006d, A new thalattosuchian crocodyliform from the Tithonian (Upper Jurassic) of north-eastern Mexico: Comptes Rendus Palevol, 5, 785-794.

Efimov, V.M., 1999, A new family of ichthyosaurs, the Undorosauridae fam. nov. from the Volgian Stage of the European Part of Russia: Paleontological Journal, 33, 174-181.

Fernández, M.S., 1997, A new ichthyosaur from the Tithonian (Late Jurassic) of the Neuquén Basin, northwestern Patagonia, Argentina: Journal of Paleontology, 71, 479-484.

Fernández, M.S., 1998, Nuevo material de Caypullisaurus bonapartei Fernández (Reptilia: Ichthyosauridae) del jurásico superior de la Cuenca Neuquina, Argentina: Ameghiniana, 35, 21-24.

Fernández, M.S., 1999, A new ichthyosaur from the Los Molles Formation (Early Bajocian), Neuquén Basin, Argentina: Journal of Paleontology, 73, 677-681.

Frey, E., Buchy, M.-C., Stinnesbeck, W., López Oliva J.G., 2002,
Geosaurus vignaudi $\mathrm{n}$.sp. (Crocodylia, Thalattosuchia), first evidence of metriorhynchid crocodilians in the late Jurassic (Tithonian) of central-east Mexico (State of Puebla): Canadian Journal of Earth Sciences, 39, 1467-1483.

Goldhammer, R.K., 1999, Mesozoic sequence stratigraphy and paleogeographic evolution of north east Mexico, in Bartolini, C., Wilson, J.L., Lawton, T.F. (eds), Sedimentary and tectonic history of north central Mexico: Geological Society of America Special Paper, 340, 1-31.

Goldhammer, R.K., Johnson, C.A., 2001, Middle Jurassic - Upper Cretaceous Paleogeographic Evolution and Sequence-stratigraphic framework of the Northwest Gulf of Mexico Rim, in Bartolini, C., Buffler, R.T., Cantú-Chapa A. (eds.), The Western Gulf of Mexico Basin - Tectonics, Sedimentary Basins, and Petroleum Systems: American Association of Petroleum Geologists, Memoir, 75, 45-82.

Kirton, A.M., 1983, A review of British Upper Jurassic ichthyosaurs: University of Newcastle-upon-Tyne, united Kingdom, unpublished $\mathrm{PhD}$ thesis.

Maisch, M.W., Matzke, A.T., 2000, The Ichthyosauria: Stuttgarter Beiträge zur Naturkunde, Serie B, 298, 1-159.

McGowan, C., 1997, The taxonomic status of the Late Jurassic ichthyosaur Grendelius mordax: a preliminary report: Journal of Vertebrate Paleontology, 17, 428-430.

McGowan, C., Motani, R., 2003, Handbook of Paleoherpetology, Part 8, Ichthyopterygia: München, Pfeil Verlag.

Motani, R., 2005, Evolution of fish-shaped reptiles (Reptilia: Ichthyopterygia) in their physical environments and constraints: Annual Review of Earth and Planetary Sciences, 33, 395-420.

Manuscript received: February 27, 2009

Corrected manuscript received: June 1, 2009.

Manuscript accepted: June 5, 2009. 